\title{
Images of Victory Images of Masculinity?
}

\author{
BERIT VON DER LIPPE
}

\begin{abstract}
The focus of this article will be on the televised constructions, both in leading American mass media and in the two leading Norwegian television networks, of Bush's announcement of victory in Iraq on May 1 2003, on board the battleship Abraham Lincoln. The article opens with a consideration of hegemony in mass media, focusing on hegemonic discourse in general, and at times of war in particular. Looking through my 'gendered lenses' might reveal how some kinds of hegemonic masculinity are embedded in this discourse and regarded as universal. The intention is to shed light on how non-hegemonic discourses (such as those in Norwegian media) are restrained, in subtle ways, from being counter-hegemonic. By highlighting the gendered perspectives the article may also serve as a kind of feminist and non-military intervention in dichotomic discourses, be it the dichotomies war-peace, victory-defeat or characteristics attributed to "we" and "them". The approach is strongly influenced by cultural analysis, critical discourse analysis as well as by rhetorics.
\end{abstract}

Key Words: rhetoric, images, metaphor, dichotomies, masculinities, femininities

\section{Introduction}

Mediated discourses of war, defeat and victory are constructed as stories and, as with any kind of story-telling, mediated war stories have clear-cut beginnings and endings. The Iraq war falls within American hegemonic discourse, with one small exception. The Bush administration knew that the US would easily win this war militarily; they also knew they would have to remain in Iraq afterwards to win the political victory, to win 'hearts and minds'. This war was, to some extent, construed as a 'different' war. But for the Iraqi people, as for other peoples who experience violence and killings as everyday events, there are, as we all know, no such clear-cut beginnings and endings.

On December 14 2003, nine months after the war had been declared, the dictator Saddam Hussein was captured. We - or, rather, the US army - had got him! That celebration, however, was more about the humiliation of the dictator than the bravura displays of the US army, as had been the case on May 1, some months earlier, when Baghdad seemed to have been conquered and any further resistance was assumed to be minor. The focus of this article will be on the televised constructions, both in leading American mass media and in the two leading Norwegian television networks, of Bush's announcement of victory on May 1 2003, on board the battleship Abraham Lincoln. 
I will mainly consider how televisual news renders its preferred version of the truth as authoritative, factual and thus potentially hegemonic. The discussion opens with a consideration of hegemony in mass media, focusing on hegemonic discourse in general, and at times of war in particular. Like all mediated wars, this war is a story about how liberators and oppressors, heroes and villains, protagonists and antagonists are constructed. These are, with only a few exceptions, all male, and always represent masculine values, whether honourable or disastrous. Looking through my 'gendered lenses' will reveal how some kinds of hegemonic masculinity are embedded in this discourse and regarded as universal.

There is no unequivocal position of women - or men - in war. There are, however, constructs and manifestations of perceptions of masculinities - or, rather, some specific kinds of hegemonic masculinities. The images of victory and of masculinities considered here will be verbal as well as iconic, though with specific focus on metaphors and the oft-hidden workings of metaphors, both overt and latent. This, I hope, may illuminate aspects of hegemonic discourse and the masculinities embedded therein though seldom discussed. It may, further, shed light on how non-hegemonic discourses (such as those in Norwegian media) are restrained, in subtle ways, from being counterhegemonic - that is, a real threat to Western foreign policy in general and to the US-led war on terror in particular. My approach is strongly influenced by cultural analysis, critical discourse analysis and rhetoric.

\section{Hegemonic Discourse - Hegemonic Masculinities}

In contemporary Western societies, power relations between groups and institutions tend to emerge through processes of consent rather than coercion or force. As many readers will know, the concept of hegemony - etymologically a Greek term for leadership or supremacy - is closely linked to the Italian philosopher Antonio Gramsci. During the fascist regime, mainly in the $1930 \mathrm{~s}$, Gramsci drew attention through this concept to the subtle pressures applied by the power elite or the dominant group in order to gain the consent of subordinated groups (Gramsci:1978).

The authority of the dominant group is not imposed on individuals, but offered to them in subtle ways. What is offered for consideration is not just an assertion of another value, or set of values. The twist is that hegemonic discourses are offered as something you already agree with, as a reflection, so to speak, of your own desires, needs and wants, and in which you can effortlessly recognise yourself. Hegemony thus seems to offer what you already want anyway. The subtlety is exactly this: whatever the values and interests of a dominant social, economic or political group, they are perceived as the values dear to everyone. Hegemony treats particular values as though they were universal, and as if consensus were simply a matter of following one's feelings or of agreeing to the obvious. "We all want the same way of life, we all feel about things in much the same way, don't we?" asks Stuart Allen ironically (107-113: 1998). To resist hegemony can sometimes seem like resisting one's own desires, particularly in times of war and especially for those more or less directly engaged in it.

The operation of a hegemonic frame should not, however, be viewed as a means of precluding the encoding of information (an aspect of journalistic discursive practices) which might explicitly politicise the seemingly impartial definitions of social reality on offer. Rather, as Stuart Allen writes, "the very authoritativeness of the hegemonic frame is contingent upon its implicit claim to objectivity, which means that it needs to regu- 
larly incorporate 'awkward facts' or even, under more exceptional circumstances, voices of dissent" (1998:102). Only by absorbing and domesticating conflicting values, definitions of reality, and demands on it does it remain hegemonic. Roland Barthes calls it 'inoculation', an appropriate dose of medicine (potential counter-hegemonic positions) for the sake of balance, but restrained within domestic frames to avoid the risk of any counter-discourse potentially competitive to the hegemonic discourse and, in this case, challenging traditional Western stability. In claiming to be universal, what ideology is actually doing is universalising the discourses of dominant groups.

A national ideology might suggest that there is a single national set of values - and types of people - made up of certain values and sentiments dearly held as part of a national myth. Ethnicity and class or gender differences within the nation are transcended. Probably, the master-spinners of identity tales designed to make some of us feel part of an imagined community are not rival ethnic groups or nationalist movements, but exist on a larger scale: the American neo-conservative power elite. They are the dominant master-spinners of today's tales of freedom, civilisation and democracy. These spinners all tend to fix, eternalise and essentialise the identities that serve as vehicles for their control.

So, too, do the 'villains'.

“One side's devil is the other side's saving grace in these duelling discourses of good and evil. On both sides of the divide, the dialectic of rival religious visions transforms the act of killing civilians and/or destroying life-sustaining infrastructures into a necessary and legitimate consequence of exercising righteous force over a demonic antagonist." These words of the American professor Robert L Ivie were spoken at the conference on War, Law and Rhetoric, which took place in Norway in 2003 (Ivie, 2003). The close collaboration, almost a symbiotic relationship, between the American leadership and the neo-conservative defence intellectuals - the Pentagon, Rand-cooperation, ie. intellectuals working in what is seen as the think-tank close to Bush and the Bush administration - may contribute to what many see as a total withdrawal from the real world. After September 11, this symbiosis was also established between government and media, to synergise shared assumptions and common messages. In the strongly patriarchal ideology of the US government, the Arab 'villain' is easily seen and condemned, whereas in the hegemonic discourse of today's America he is mediated and seen as genderless - as indeed he is in Western news stories generally. The images of masculinity - singular or plural, iconic or verbal - are seldom discussed.

The stories told of history, war, defeat, victory and glory spring first and foremost from masculinised memory, masculinised ambitions, humiliation and masculinised hope told mainly by a males in power positions (Enloe, 1990, Bell, 1995, Elshtain, 1987).

R.W. Connell's concept of hegemonic masculinity seems to fit into this mental schema. Connell considers the power relations between men, and his hegemonic masculinity concept is intended to show groups of men in power positions at the cost of those in subordinated positions within a masculine hierarchical structure - a structure to which both men and women have to relate (Connell, 2002). He makes no reference, however, to women in power positions, or to the process of socialisation into a specific kind of masculinity, and he overlooks the fact that a certain kind of hegemonic masculinity is not perceived as hegemonic among males belonging to other groups in power - or even without it. His perspective thus ignores the complexity of human relationships and among human beings, be they male or female. Despite all these objections to his analysis, I find his understanding of hegemonic masculinity (I prefer the plural 'mascu- 
linities') useful in underscoring at least some important aspects of made-in-America masculinities as an integral part of the hegemonic discourse referred to above.

Embedded in stories of war and victory one might see, as I do, the kind of hegemonic masculinity Connell describes: “...it is essential to bring men and masculinity explicitly into the analysis of the state, especially in an organisation as large and complex as the state... it is important to recognise the distinction between hegemonic and subordinated masculinities. The masculinisation of the state, accurately identified in feminist theories, is principally a relationship between state institutions and hegemonic masculinity" (2002:105). The next step is to look at the mediated stories, and spectacles of victory, emanating from the Iraq war. The manifestation of masculinity on board the Abraham Lincoln will be seen partly as spectacle, not different from the construction of masculinities in film and popular culture which are in part the manifestation of a specific kind of masculinity partly hidden in the President's victory speech.

\section{George W. Bush - Icon of a Remasculinised USA}

The declaration of victory was televised in every detail, mainly for the US public, but simultaneously for a global audience. They, and we, were shown aircraft bringing the 'hero', President George W. Bush, to the Abraham Lincoln. They, and we, watched his arrival on board, which represented military hegemonic masculinity. Bush's ethos was already shared by many Americans and after 9/11 he had manifested the virtues so important in many cultures, not least in American; he had been firm, strong, willing to mobilise the army on the high seas, in the air, on land and even in the penetration of Afghan caves.

In the immediate aftermath of $9 / 11$, those Americans who worried about the impact on civil rights or civil liberties in general, or those who protested against hate crimes and round-ups on ethnic grounds, found themselves excluded from the discourse, marginalised as unpatriotic and unable to make an impact on public opinion (Schechter, 2003:140-141). The president had, for quite some time, been portrayed as a bold hero and an incarnation of the brave patriotic father of the country. Before May 1 he had already become an icon of hegemonic masculinity.

The blurring of the factual and the mythical leads one to read the spectacle of the President's arrival by aircraft (not helicopter) as if it was an episode in a war film. In her book The Remasculinization of America, Susan Jeffords (1989) discusses the cultural shift from the ends to the means and technologies of war. The combination of man and machine is more perfect than either man or machine alone. The televised spectacle of Bush's arrival could be seen in the context of what Jeffords describes as a 'remasculation' of American culture, and as one dimension of hegemonic masculinities (the masculinities of a Rambo or a Terminator in American fiction, competing with other masculinities which express more intelligence, modesty and reflection, a masculinity we see in recent fiction such as in the film The Matrix). On that day and at that moment, Bush had nothing to fear - his strength and authority were at their highest point. His masculinity was not in question.

If there were any kind of erotic connotations perceptible in Bush's appearance and his performance on that day, they might rather have been the erotism of the advanced high-tech weaponery and aircraft the on board on Abraham Lincoln1. The glorification of high-tech machinery and weapons may thus be seen as reproducing a kind of ideological masculinity. The rhetoric of the physical location is an integral part of the rhetorical spectacle (see Cohn, 1986). 
The hyper-machismo of yesterday has been modernised. Bush may very well, on that day, have been seen as not quite the same as the anachronistic John Wayne/Rambo/Terminator-character. He arrived, he had delivered (a successful war) and he was welcomed as a civilised and compassionate Christian father - and yet there was some element of the old-fashioned Rambo/Terminator about him. The 'villains', on the other hand, serve as icons of a brutal and uncivilised masculinity - which may indeed be both a fact and a truth. The masculinity of presumed primitive vengeance belongs to the 'other' and needs to be constructed accordingly. Hiding or suppressing any similarities between 'our' Western masculinities and the enemy's, helps create a dichotomy: the categorisation of 'good-doers' and 'evil-doers'.

According to Barthes, myths do not deny things; on the contrary, the function of myths is to talk about them, thus purifying them and making them innocent. Myths give things natural, eternal justification and clarity - a clarity not of explanation, but of stating a fact. The compassionate and post-modern myths of masculinity are attempts to pass it off as natural and universal, free of problems. To many Americans this was probably how Bush appeared. He had shown muscle and strength, at least on a metaphorical level: moral muscle and moral strength.

The rhetoric of Bush's physical surroundings on May 1 is precisely the rhetoric one is used to seeing in Hollywood films (no wonder, since, as we know, movie-makers are among the master-spinners). Females are almost absent - literally and mentally. Literally, because the applauding audience (officers, admirals and ordinary marine staff) were with few exceptions male, pale and not pale (white or African-American); mentally, because the gender or masculine connotations often seem to be taken for granted.

Roland Barthes' understanding of myth may also illuminate this taken-for-granted aspect of iconic images, dynamic or not, giving an impression of simply seeing the world and the surroundings as they really are and not as highly contingent and ideological (Barthes, 1959). Watching a dozen male ministers, admirals, soldiers or officers on a television screen, most people only see ministers, admirals, soldiers or officers. That these persons may be exclusively male is often overlooked. There were 5000 persons on the Abraham Lincoln, and almost all were male. Had there been a group of 5000 exclusively female ministers, admirals, soldiers or officers on a war ship, they would probably be perceived first as females. And would they have been seen or perceived as ministers, admirals, soldiers or officers at all? It is difficult to say what kind of connotations a group of 5000 females would have evoked on that day and in that place. Would they have been seen as persons of military power? Or would some people have even laughed, seeing these females as a comedy and completely ridiculous?

One way the myth functions is to naturalise men in power positions to such an extent that some kinds of hegemonic masculinity still seem to be an integral part of what may be called hegemonic discourse. The spectacle on the Abraham Lincoln signified strength, potency and high-tech sovereignity, which, on the mythic level, made overt references to any kind of masculinity superfluous.

The best-known example given by Roland Barthes, in his analysis of the front page of the magazine Paris Match some fifty years ago (Barthes, 1959) to explain how myths function through naturalising ideology, underscores this. Barthes sees the following: a black soldier is saluting the tricolor, the French flag. Read at the mythological level, the naturalisation of what one sees (when not registering the colonised or imperial aspect of the photo) sustains the myth: formerly colonised people, represented by a black male, are naturally serving the French army. When a few women, nowadays, are seen in similar 
situations, I am inclined to see much of the same mythical disguise: we all, independent of gender and colour, race or ethnicity, naturally serve our country.

"Fighting the femininisation of a society means taking three steps to heaven", Steve Niva writes ironically (Niva, 1998). The sensation of being close to heaven might, on this occasion, have been evoked.

\section{A Construction - and Perception - of Victory}

Kairos, the rhetorical situation, is a moment at which it seems appropriate, or even urgent, to do - or say - a particular thing. As some readers will know, saying is doing and doing is saying. Rhetoric is essentially situational. What matters, first and foremost, is not what rhetoric means, but what it does in and with the world. For mass media and for the USA media in particular there have been rhetorical situations almost every day since the tragic and dramatic terrorist attacks. The outside world, the real world, has been filled with action and drama on such an extraordinary scale that the American media have tended to downgrade serious news and global coverage. "With the emergence of 'terror-tainment", writes Schechter, "came the blurring of the lines between jingoism and journalism, punditry and commentary laced with patriotism, while all other viewpoints moved out of sight. As a period of 'patriotic correctness' began, self-censorship and corporate censorship snapped into place" (2003:141). As the media marched in step with the government, dissenters were hard to find.

In a climate in which there is no marketplace of ideas, the rhetorical imperative may, however, have been such that the American leadership found it essential to construct the spectacle of victory that day. Having experienced more difficulties than envisaged on their journey to war and in reaching their goals, both in Afghanistan and in Iraq; having searched for bin Laden, Mullah Omar and Saddam Hussein without success; having found no weapons of mass destruction in Iraq, it was of the utmost importance for the president to demonstrate success. The American liberation of Iraq was, to the neoconservatives' surprise, not seen as a liberation by all Iraqis. The blurring of fact and fiction occurs on different levels, and liberation easily becomes occupation and vice versa. Baghdad had fallen (the Iraqi resistance had been weak); the statue of Saddam Hussein had fallen and the victory now seemed to be within reach.

To better understand the rhetorical situation (kairos) on that day, I shall introduce some aspects of the ideological dimensions relevant for its analysis. The atmosphere on May 1 2003, and not the least the atmosphere among those serving in the navy and present on the Abraham Lincoln, had all the elements of victory and it was televised as if the Iraq war had been won. The victor had arrived. The goal had been attained. There was a mission. There was no course other than that of attaining the prescribed goal. Along the way, Americans are told that things are going well - so far so good - 'we will stay the course all the way'. If questions about continuing the war are asked, the answer is, 'the plan is in motion, we have started down this road, and we have to continue'. And they had continued - to the bitter end (Americans like to go on single tracks to visible goals - in one direction and without stopping - and they prefer to travel alone). The American concept of policy is, according to Johnsen and Lakoff (2000) and Chilton (1999) based on the 'path metaphor', a single goal from which one must not deviate or be sidetracked. The goal and endpoint is the solution to a problem. The schema does indeed carry its own logic within it. Slowing down, changing track, reversing or choosing an alternative way to go would be almost inexpressible and, perhaps, unconceivable 
- weak, soft, 'sissy-ish', 'wimpish' and feminine. This is the way the discourse goes, along this kind of path.

Such a perspective discourages looking beyond the end-point or seeking alternative routes for, in the hegemonic American war/victory discourse, simply pausing to think is seen as feminine. In this mental schema it is vital to get there, whatever the obstacles and whatever the consequences. On May 1 the goal had to be reached and celebrated on the Abraham Lincoln.

These are some of the characteristics under-pinning the rhetorical situation on that day. Bush, speaking or preaching to an applauding public, was televised, and the event was constructed as the culmination of a glorious journey now coming to an end. The speech as such, televised in full, will therefore be given detailed attention.

I am, of course, fully aware of the polysemic potential, or the multiple possible meanings, inherent in iconic signs and the different perspectives in relation to the above analysis, as well as to my analysis of the speech. By that time the USA had been at war for more than one and a half years. The American people had largely been told, visually and verbally, the story that the Pentagon and the power elite had decided it must hear and see. This does not, however, mean that the hegemonic discourse was accepted or read in the preferred way by all Americans, for hegemony, no matter how strong, always encounters some resistance. Furthermore, the speech televised live as a news and victory story, will be experienced in a specific atmosphere, and probably not very differently from the enthusiasm on the Abraham Lincoln. What often characterises the reception of such speeches - if the rhetoric is effective - is not any analytical reading and reasoning but, rather, an immediate feeling of belonging, of being part of some great collective identity, of travelling towards some pre-defined goal.

\section{Bush's Speech}

Exordium, or the opening of a political speech of this kind, has to establish a close and almost intimate relationship between the speaker and the listeners. The president in this situation chooses to put himself and his leadership in the background. From the very beginning he offers a tribute to the people, to those seen as 'ordinary folk', and to what is done in the name of freedom for ordinary folk - and by ordinary folk. Bush's exordium was, "Thank you all very much. Admiral Kelly, Captain Card, officers and sailors of the USS Abraham Lincoln, my fellow Americans..." What counts, is to give an impression of being there and having done something, not for oneself or for any specific group, but having fought for some great ideal on behalf of the people one is elected to serve. Not only admirals and captains are praised as heroes; so are the sailors - and all 'fellow Americans' as well. This is, as we know, the classical manner in which to uphold one's ethos (which, in this instance, was not at risk).

"In the battle of Iraq, the United States and our allies have prevailed," Bush continues. The reference to 'allies' provides a clear association with the glorious victory of the Second World War. This is an important image because analogies from this war may be brought forth more or less as one chooses, and can be used to gain support before entering into any war: are we willing to make the same mistake as Chamberlain who claimed 'peace in our time'? Are we willing to risk the same threats as represented by Hitler and the Nazis? If this kind of analogy succeeds, and becomes an adequate reference-point, what follows will easily be accepted; the rhetoric will easily be perceived as non-rhetorical and (almost) literally true. 
The introduction of the great and all-embracing 'we', is the next step on the rhetorical journey (within the greater journey to victory). Having established the optimal connectedness to his audience, Bush may now be sure that 'we' is taken for granted: "In this battle, we have fought for the cause of liberty and the peace of the world" (the italics are mine). The magic of abstraction starts working, even without using the magic words freedom and peace. The President himself, and his neo-conservative followers, are kept in the background: it is "...you, the members of the United States military, who achieved it. Your courage, your willingness to face the danger for your country and for each other, made this day possible. Because of you, our nation is more secure. Because of you, the tyrant has fallen, and Iraq is free." This is the voice of a proud, compassionate and caring father, a father who gives credit to his family rather than praising himself and his leadership.

The epeidictic (a rhetoric of praise) is then explicitly linked to the Second World War (a reference frequently made): “...the daring of Normandy, the fierce courage of Iwo Jima, the decency and idealism that turned our enemies into allies...in defeating Nazi Germany and Imperial Japan, Allied forces destroyed entire cities, while enemy leaders who started the conflict were safe until the final days. Military power was used to end a regime by breaking a nation." For an analogy or a metaphor to be recognised and understood, these rhetorical perspectives must create some tension, and experienced as logically even if not literally true, and simultaneously not totally meaningless; we are invited, to look for some meaning, some similarities, between two different phenomena. The linked terms have to be understood by as many as possible as having certain common features, while at the same time they do not really 'fit' (this is what I mean by 'tension'). Often, even most often, there are no such tensions, and probably no such tension was perceived by the target group in the actual rhetorical situation. If they were noticed, however, the metaphors may have been perceived as natural and suitable.

The metaphors - the Allies, Normandy, Nazi Germany, Imperial Japan - whether recognised or not, may become so vivid that they are perceived more or less as images of what has been and what has to be done: this is exactly and literally what it is all about - the here and now! As we fought the Nazis or the Japanese, we now fight the terrorists. Furthermore, just as Germany and Japan were defeated and have since become democracies, the same will happen with Iraq. The concepts of war and peace are blurring; war becomes peace and vice versa. The President, who himself never served in the army, now shows some of the same virtues - and masculinities - as he did during his service as Governor of Texas - fighting crime by prescribing more death penalties than any governor before or after him. The morality of the strong pre-modern father grows more and more manifest. Margaret Thatcher acquired the nickname 'iron lady' because of her boldness and willingness to initiate the Falkland war whereas Bush is naturally a strong man showing muscle.

The hegemony seems complete, and the discourse (the analogy of the Second World War) goes without saying. Within such a discourse one finds a blurring, not only between fiction and fact, freedom and occupation, but also between dichotomies in general, which in rhetoric are labelled oxymora: figures of speech where two opposites are consciously juxtaposed (as in the expression 'false truth'). When manipulated for ideological reasons, antonyms easily become synonyms and vice versa - and this occurs throughout the speech.

Analogy is not only appropriate to the framing of an important story. Rhetoric is an almost magical use of speech to evoke the desired mental imagery in the public, whether the audience on board the Abraham Lincoln or the American audience in front of the television screen. The visuality of verbal rhetoric should by no means be under-esti- 
mated, for images consist of much more than what we can literally see, and mental images may be even more influential because they may be seen, or perceived, as literally true - representing the real. Metaphors are images, not pictures (Lippe, 1999).

Although $9 / 11$ is present as part of the ideology and the hegemonic discourse, Bush's speech does not begin with such an explicit reading - exordium is seldom produced with reference to dramatic moments of history. The first words have to be cautious and mild and, as we have seen, address the heroes as 'ordinary folk'. When ethos is established, the dramatic images are brought forth.

Bush then turns to the Iraqi people and the 'images of the fallen statues' as vivid proofs of 'a new era', the destruction of the Taliban and the 'hunting down of al Qaeda killers 'from Pakistan to the Philippines to the Horn of Africa'. Men have always hunted animals to survive, but here humans are being hunted down. Whether this metaphor is recognised, is impossible to say for certain. Probably, the rhetorical situation was such that hunting down, by protagonists of civilisation, might be perceived as civilised, connoting strength. In the story of the brave fight for freedom, the weapons of mass destruction are mentioned several times to emphasise that no terrorist network will acquire weapons of mass destruction from the Iraqi regime because that regime no longer exists. Bush thus makes explicit the links between the al Qaeda terrorists and the Iraqi dictator - links without any basis in reality. His speech evokes mental images more fictitious than many Hollywood war films highlighting American masculine strength - a blatantly false mix of Nazis and terrorists, for if the Nazis and Hitler been mere terrorists they would not have represented any real threat to the world.

The time has come to look forward, to what still has to be done, because "... any outlaw regime that has ties to terrorist groups and seeks or possesses weapons of mass destruction is a grave danger to the civilised world." To avoid emphasising the dangers to come, reminders from history are continuously brought up. When, in the end, he reminds the audience that "the war on terror is not over, yet it is not endless", the potential dangers on the road ahead are minimised.

Conclusio is, like exordium, portrayed as the compassionate father taking care of his nation - his family metaphorically as well as literally: "After service in the Afghan and Iraqi theatres of war, after 100,000 miles on the longest carrier deployment in recent history, you are homeward bound. Some of you will see new family members for the first time -150 babies were born while their fathers were on the Lincoln. Your families are proud of you, and your nation will welcome you." The 'you-ing' has to be repeated to re-assure them that he and his government are of little importance and that the 'you' is what counts, and thus the 'we' is naturally re-created.

Bush pays tribute to the dead: "We are mindful, as well, that some good men and women are not making the journey home. One of those who fell, Corporal Jason Mileo, spoke to his parents five days before his death. Jason's father said, 'He called from the centre of Baghdad, not to brag, but to tell us he loved us. Our son was a soldier'... Yet we pray, in God's time, their reunion will come." The divine dimension of the ongoing mission and the Nation's sacrifices to fulfil it are again made explicit: "Those we lost were last seen on duty. Their final act on this Earth was to fight a great evil and bring liberty to others...And whenever you go, you carry a message of hope - a message that is ancient and ever new. In the words of the prophet Isaiah to the captives, come out, and to those in darkness, be free. Thank you for serving our country and our cause. May God bless you all, and may God continue to bless America." 
The American, and Bush's, mission is to bestow its values on the benighted world. The religious rhetoric must be seen in the light of the invincible march to the East to vanquish the powers of darkness. The religious paternalism from the Old Testament eye for eye - is to be taken literally.

Since these religious rhetorical aspects might be somewhat under-estimated in Europe (possibly to reduce similarities with Islamic fundamentalism) I must emphasise the relevance of deep-rooted Christian fundamentalism for the neo-conservatives both inside and outside the power elite.

In his book Made in Texas (2003) Michael Lind gives a brilliant - or frightening illustration of the religious fundamentalism so strongly influencing, not only the Bush rhetoric, but the very ideological perspective of the Bush family, and some other families in Texas. Not only has Bush Jr criticised Darwinian evolution; he is also influenced by those Southern Protestant fundamentalists who believe that the 'Kingdom of God on earth will be established by human beings, with divine inspiration but not divine power' (2003: 112). Lind gives a thorough analysis of how Jerry Falwell, Pat Robertson and other famous preachers explicitly linked, and continue to link, the acts of terror to religion, and in particular to the impact of the Old Testament concept of morality on Bush's milieu - and this includes the patriarchal family structure. Abortion amounts to killing, while killing by bombing, shooting and the death penalty are construed as ways of giving life. The allusion to the prophet Isaiah is more than mere rhetoric; it is also symptomatic of total adherence to the Old Testament. Lind, a moderate Democrat himself, illuminates the similarities between Orthodox Jews and Southern Protestants, combined with what he calls 'Herrenvolk visions' (152-160).

Similar aspects of religious fundamentalism are made manifest by Carol Cohn (1986, 1993) who, having interacted for several months with American defence intellectuals, also warns against under-estimating religious fervour as mere rhetoric. Cohn points to the first atomic bomb test, which was called Trinity - the unity of the Father, the Son and the Holy Spirit, the male forces of Creation. The physicists who worked on the atomic bomb exclaimed, when they witnessed its success, "It was as though we stood at the first day of creation" and the defence intellectuals referred to themselves as 'the priesthood'. Thus this discourse, as is the Bush discourse, is permeated with references to their supernatural power and supernatural virtues (virtue etymologically meaning manliness).

To not to take Bush's religious rhetoric seriously is to under-estimate how it is linked to different cultures and sub-cultures as well as to Christian fundamentalism. Today's quasi-religious 'techno-euphoria' may, perhaps, be seen by some as a greater threat to the world than the threat of terrorists. That the whole speech can be analysed from a religious perspective in no way reduces the masculinities also embedded therein. In today's climate pure phantasy would be a woman as president arriving on the Abraham Lincoln as Bush did. Can one imagine Hillary Clinton, for instance, landing on the battleship in a Rambo-Terminator-like manner?

Although Bush made references in his speech to an ongoing war yet to come and to be fought, it is impossible to alter the effect of the whole choreography of the Abraham Lincoln scenario: mission accomplished. The rhetorical construction of the physical surroundings, so well planned, would some months later become a rhetorical disaster.

The very nature of the speech is hidden by the story's natural-seeming factuality - a story without class or gender distinctions. Bush's appeal to his audience as a collective, with a collective identity, may have been successful on that day, albeit probably not at the level of earlier days and certainly not as the kind of collectivity perceived on 9/11. 
But what about this spectacle, or construct of victory, in the Norwegian televised news stories?

\section{Norway - the Rhetorical Situation}

For the first time in (post)modern history a Norwegian government opposed US foreign policy and the US occupation of Iraq, claiming - as did other 'old-fashioned' European countries - that Hans Blix and the weapons inspectors, should first finish their work. The opposition was, however, much stronger among the Norwegian population than among the political power elite. The strongest demonstrations since the Vietnam war had taken place, involving protestors belonging to different political parties. The climate in Norway, and in most European countries, was thus very different not only from that in America but also in comparison with that at the time of other, earlier war involving the US (the war in Vietnam is of course an exception).

In the Norwegian mass media there has not been any hegemonic discourse. Not only has the actual war been sharply criticised, but the alliance between Ariel Sharon and Bush is opposed by a majority of Norwegians and by the leading media. In contrast to American, the Norwegian media have exposed the public to alternative stories of the Iraq war. The rhetorical situation was very different from the American.

Needless to say, American popular culture is, in Norway as elsewhere, much admired - many say it is even more popular in Norway than in other Scandinavian countries. Rambo, Terminator and other violent films are seen and enjoyed by hundreds of thousands of Norwegians, without, it seems, their having much impact on how George W. Bush is perceived although he has been ridiculed to some extent because of what many Norwegians see as ignorance and lack of political experience, particularly in foreign policy (among the European political power elites only Silvio Berlusconi of Italy could have acted the way Bush did as he arrived on the Abraham Lincoln). Norwegians in general mistrust the policies of the American administration. Neither does high-tech weaponry evoke the same passions among Norwegians as it seems to among Americans. If Bush is an icon in Norway, it is not as an icon of any hegemonic humanity. What seems to be common to both countries, however, is that masculinities are not seen - or at least not discussed.

Neither is it relevant to talk about any counter-hegemonic discourse prevailing in Norwegian mass media. There is some kind of negotiating discourse, supporting the US on some issues such as the Afghan war (on terror) and opposing it on others. Some media have invited a kind of counter-hegemonic discourse. However, the rhetoric of the spectacle on the Abraham Lincoln and the American hegemonic discourse was of a quite different kind.

I shall now take a closer look at how Norway's two most important television networks, NRK (Norwegian Broadcasting) and TV 2, re-constructed the American construction of victory live from the Abraham Lincoln. What might the similarities and the differences be? To what extent was the hegemonic discourse either challenged or maintained? Which were the common taken-for-granted aspects - or facts - of these constructions in the two dominant television networks, the public broadcasting NRK and TV 2? 


\section{The Norwegian Televised Construction of the Spectacle on the Abraham Lincoln}

NRK had it as its fourth news item. The Norwegian princess and her husband were honoured with first place, to talk about their new-born baby girl, and for six minutes Norwegians watched the happy young couple, the baby on her mother's arm, the proud father by their side. Two other news stories followed before the window opened on the spectacle aboard the Abraham Lincoln.

As viewers saw the aircraft and Bush's arrival, the anchor reported: "A well-rehearsed performance... as Bush arrives on the Abraham Lincoln. Bush does not use his ordinary transport vehicle, the helicopter, but a fighter [plane]... for a short time he even held the joystick..." All this was said in quite an ironic way. Bush's arrival was, in some respect, similar to the American version. What differed, however, was the message: 'a well-rehearsed performance', Bush's arrival 'by a fighter - not the helicopter' and so on.

This is an excellent example of the importance of verbal rhetoric in the mediated story. Images are said to dominate every news story nowadays. This is both true and untrue; true because we actually see what is happening, untrue because we may be led to underestimate the importance of the verbal. Roland Barthes' famous article, 'Rhétoric de l'image' (1963) may help to elucidate what is at stake here. According to Barthes, the verbal text, on the denotative level, functions as an anchor of the polysemic image, telling the reader who is photographed, what the location is and, implicitly, why the photograph has been taken. Thus the reader will know whether the soldiers are American or Spanish; if they are in Afghanistan, Sudan or Iraq. This is, of course, important. Spanish soldiers are more valued to Spaniards than are American soldiers, which is true for every nation at war. It was not necessary to identify the President by an anchor of this kind, but when it came to the nationality of the navy staff - in theory some might have been British, Polish or even Spanish - the location was of prime importance - this did not take place in the Gulf region; the Abraham Lincoln was located safely off the American coast. Even more important, perhaps, is the description of the spectacle as a 'well-rehearsed performance', and the reference to Bush's holding the joystick which might have emphasised the made-in-Hollywood aspect of the performance. On a connotative and ideological level, the verbal message functions not so much as anchor but more as a guide to a desired reading of an almost antagonistic nature. The iconic polysemy is thus limited in a subtle way - as is the verbal message introducing the story. Although machine-man Bush does not connote hegemonic masculinity to most Norwegians, the president was probably perceived by many Norwegians more like an actor in some sort of comedy than a hero or a political leader.

Only part of the exordium is included in the NRK construction: "Major combat operations in Iraq have ended. In the battle of Iraq, the United States and our allies have prevailed. And now our coalition is engaged in securing and reconstructing that country." For a speech to be successful, the speaker has to be seen as a person with a strong ethos. Since in Norway this ethos is only strong for a minority, the meaning of the public applause for the president on that day would differ from its meaning in the US.

It is much the same for gender blindness. Barthesian mythic reading and seeing prevails here as well. Omitting to mention the masculinity of war seems to be universal. In Norway, as elsewhere, masculinities are seldom noticed because they are taken for granted, normal and therefore genderless. The male public was an applauding, and genderless, public. 
The anchor person underlines that in his speech Bush says the war is not over yet, thus perhaps giving the president some credit for understanding, at least, that there may be difficulties and dangers to come. "The transition from dictatorship to democracy will take time, but it is worth every effort. Our coalition will stay until our work is done. Then we will leave, and we will leave behind a free Iraq," are the words Norwegians heard, and the interpretation, by most Norwegians, of the rehearsed, made-in-Hollywood performance could have been hostile. Bush's last words, “...we will leave behind a free Iraq," were, for many viewers, euphemisms - meaningless words.

Then viewers were informed that Colin Powell and other representatives of the Bush administration would be travelling in Europe to discuss the situation with their colleagues, and this is followed by a brief epilogue. A well-known academic and expert on such issues, Henrik Thune, is in the studio. He questions any suggestion of victory, and asks when the war had ended, since many Iraqis see this as an occupation, not a liberation. The Iraqis need to experience safety, reconstruction and better living conditions. They have to trust the government in transition... we the viewers are further informed about the difficulties the Americans envisage in winning hearts and minds, not least the hearts and minds of the Shiia Muslims, and we are also confronted with these Muslims' ties to Iranian Shiias. Finally, Thune warns that a political victory ought to mean stability in the whole region. Experts such as Thune are frequently heard and seen on Norwegian screens, in contrast to what the Americans are watching.

Whether or not NRK's construction of the event may be called counter-hegemonic could depend on one's political persuasion, but I find it difficult to call it so. Perhaps, as will be discussed later, it might be more appropriate to call it a negotiating position, critical to some extent, but not unmasking any myth or American hegemonic discourse as such. It is clear that there are different discourses in international relations, and different perspectives among western political power elites in relation to the UN and to the problems of war and peace.

\section{The Story on TV 2}

TV 2, in contrast to NRK, highlighted the Abraham Lincoln spectacle as its main news story on May 2. Even the baby princess was over-shadowed. But Bush's arrival was not given the primary role. The spectacle was introduced by showing American soldiers fighting in Iraqi streets while the voice-over declared “...no public statement of victory because this would have obliged the Americans to free imprisoned Iraqi leaders and other Iraqis in prison" thus depicting the spectacle as one resulting more from chaotic circumstances, than from certainty or victory. "The Iraqis themselves do not believe that the war is finished." A male Iraqi then appears on screen in close-up. He talks about his lack of confidence, either in Americans or in peace; he had experienced nothing but insecurity, anxiety and death, and he feared for his family and for his own life.

In contrast to its coverage of the first Gulf War, Norwegian television coverage during this war gives voice to many people who are not just crying or screaming. Indeed, they are most often calm and serious, suggesting trustworthiness. They are not depicted as uncivilised (as was the case during the first war) or like hordes of animals.

After this introductory episode we enter, as it were, the very spectacle that the Americans wanted to sell to the world. The Abraham Lincoln spectacle as story thus becomes a chapter or a scene in another, broader, story, one told by the Iraqis themselves. Bush becomes not so much the protagonist, since in this framing he is to some extent depicted 
as someone far away from the arena of war and from the lives of those he has 'liberated'. By choosing to foreground Iraqi people and their difficult conditions, TV 2's 'exordium' may be seen as more oppositional than that televised by the public network. We, as spectators, are invited to take the side of the Iraqis, before the entrance of the president himself.

Bush had, in a way, been construed before his appearance as someone living a life totally alien to the Iraqis - and without too much glory. As the president arrives on the aircraft carrier, the voice-over says, "Bush was celebrated on land today; tonight he is celebrated on sea. The 5000 soldiers who have returned to their homeland, are the lucky few. The USA is prepared to stay in Iraq for nearly five more years". The celebration referred to may be read as ironic - celebrating the chaos, the anxiety and fears of the people one is claiming to liberate? We are then told that Bush's 'fight' (not 'war') against terrorism is far from over.

And, only now, has the time come to hear a few words of the speech, the very core of the US story. "Any outlaw regime that has ties to terrorist groups and seeks or possesses weapons of mass destruction is a grave danger to the civilised world and will be confronted." The outlaws, terrorists, and weapons of mass destruction are juxtaposed as integral to the world of the 'others'; the common dichotomies are chosen as metonomy for the whole speech. The adjective 'civilised', in this framing, might easily slip into its opposite meaning (not-so-civilised world) in the eyes of some television watchers; the empathy already established towards the Iraqis makes such an assumption possible.

Although the framings and the stories in the two Norwegian broadcasts differ, they are both symptomatic of the disagreements and the different discourses in the contemporary war on terror. The Iraqi voices heard and the Iraqi people seen in the Norwegian depictions are, perhaps, among the most obvious differences between the American and the Norwegian discourses on this occasion.

Some concerns remain, however, such as why it is difficult, in the televised Norwegian constructions, to discuss counter hegemonic discourse. For how long will opposition to the US hegemonic discourse be made manifest in news stories? And, as a curiosity: Norwegian soldiers are present both in Afghanistan and in Iraq - not, we are told, as soldiers, but as part of humanitarian and stabilisation activities. This leads me to the last chapter of my story.

\section{Epilogue - Opening the Door to Doxa}

I will now open a door to doxa, the room one seldom enters because what one may find there is of little or no interest. It is a room containing the assumed, or what is understood merely as common sense. My metaphorical - and epistemological - gaze may reveal aspects of common traits in discourses on war, peace and victories, aspects seldom discussed (Tickner, 1992). My intention is to shed some light on what may be barriers to other perspectives on such difficult issues thus limiting the possibilities for alternative stories or counter discourses to be heard.

Metaphor is part of thought and of the way we understand society. It is a universal property of the mind and of languages: distant and 'unknown' things or abstract ideas are represented in terms of what is familiar - often in terms of bodies. Social, economic and political realities are among the abstract systems of thought that require metaphor in order that to be conceptualised and communicated (Chilton, 1996:39). The realities 
of war and terror are no exceptions. In mainstream theory of international relations, among the so-called realists, the metaphor is taken to be anything but realistic. Yet the current understanding of foreign policy is metaphorical through and through. 'Stability of balance', 'pillars of stability', 'military strength', 'pre-emptive strike', 'deterrence' and 'containment' are all metaphorical terms indicating a certain perspective from which the world is seen. How metaphors may both be constituted within given power structures and, at the same time, are constituting them, can be illuminated by the game-metaphor.

People play games which, to some extent, are gendered - embedded with masculinities and femininities. According to George Lakoff and Mark Johnsen (2000) the prototypical game people in the USA play is the zero-sum game 'winner takes all'. Mathematicians may invent endless elegant games of cooperation, but in the end, on the grounds of socialisation into the zero-sum prototype, the hegemonic discourse will win and fix the game people play.

Game theory and rational action have a profound effect on our lives and in ways we are not always aware of. They have been used since the early days of the cold war as ways of making foreign policy and war more 'rational'. Just as institutions are constructed according to the time-is-money metaphor, so are they constructed according to the rational-actor model or metaphor. Rational action in a market is often defined as nothing more than acting so as to increase wealth, to maximise profits and minimise costs and losses. In such examples, institutions are rational actors and this is of course true of media as commercial industries. 'Rational action' does not just describe so-called natural human behaviour, but is made prescriptive and thus normative. This perspective offers at best a particularistic view, omitting a lot of other human characteristics.

Lakoff and Johnsen believe that rational-actor models in themselves are morally blameless. They are just models - mathematics plus metaphors. The manner in which they are used is, however, another question. This is where moral judgment and morality enter into it. But such morality is not part of rationality as defined by models of rational actions in game theory.

Hegemonic security discourse and the discourse of victory are based upon suppositions about human nature and suppositions of war as, often, the only means to stability. War easily slides into peace, and victory comes to mean preparation for new wars. The assumptions the realists use when analysing states and explaining their behaviour in the international system are heavily dependent on characteristics that we in the West have come to associate with masculinities - hegemonic masculinities - such as autonomy, sovereignty, autonomy, independence, power, strength and honour.

The fear of the other, the fear of dependence (and, concomitantly, of lack of autonomy) is a male construct (Tickner, 1992). In the name of universality realists and neoconservatives have constructed a world view based on the experiences of some (or even a few) men - thus a world view offering only a partial view of reality and from a specific perspective. By omitting this kind of particularism, theorists opposed to realism come short in their critique, not only of hegemonic discourse but also of similar international relations theories: making manifest the gendered fantasies of autonomy, one also makes manifest the limited perspective on which hegemonic realist thinking still seems to depend.

Ann Tickner provides an excellent analysis of this specific particularism (1992) underlining how reproductive activities (labour of various kinds) requires an environment that can provide for the survival of infants and behavior that is interactive and nurturing. As both males and females take part in such activities, and since we all know 
how integral these activities are to life, we need to re-conceptualise, or at least to include, the rationality connected with nurture, empathy and dependence (is it possible to assess such activities only as numbers or profit? See also Di Stephano, 1983).

Although the particular referents for masculinities and femininities vary cross-culturally, they are interrelated within any particular culture. Gender infuses all our identities so that race, age, class, ethnicity, ability, and nationality are also gender-specific identities. Moreover, gender identity is so entangled with sexual preference, presentation and performance that issues of self-esteem surface when issues of gender come to the table. As men are not born aggressive or simply driven by the rationality described above, one has continuously to remind them of their maleness, boldness, strength and sexual identity. In times of war the polarisation of masculinities and femininities increases. The role of women as caretakers and men as defenders of honour and of property are emphasised. Females also become targets of a different sort from men; their bodies become targets and are commonly invaded - raped (Enloe, 1990 and Bell, 1992). In Iraq today we seldom see females on the streets. Why? Where are they? What do they do? Is this overlooked by journalists, and thus by media, because it is taken for granted? All of us, men and women, have the same interests and share the same values, do we not, and class, ethnicity or religion are irrelevant (Grönfors, 2002).

Doxa is of course not the only perspective from which to constitute a counter discourse; it is, however, necessary to include it in any discourse, and not only to challenge the particularism and political construction of rationality in strategic thinking about war since the dichotomies attributed to 'us' and 'them' may become much more problematic to construct when similarities between cross-cultural assumptions of masculinities and femininities are revealed. Evil-doers may more easily be identified on both sides. By highlighting the hegemonic masculinity embedded in contemporary political and military activities worldwide, I hope to have shed some light on alternative ways of telling stories about war and peace and celebrations of victories - whether among academics or non-academics, politicians or journalists.

\section{Note}

1. The USS Abraham Lincoln is represented on May 1 as news on the main web-site as follows: "USS Abraham Lincoln set the record for the longest naval deployment by a nuclear powered aircraft carrier in history, deploying for almost 10 months, and steaming over 100,000 miles. For a Carrier Strike Group, this is the longest deployment in the last 30 years. The USS Lincoln Strike Group was involved in combat support of three major operations: Operation Southern Watch, Operation Enduring Freedom, and Operation Iraqi Freedom." Then follows detailed information of Air Wing equipment to be delivered, and of media organisations on board, including CNN, MSNBC and the BBC. We also learn that two nuclear reactors and four shafts were part of the equipment. Dozens of aircraft, missiles and weapons are photographed. Many photos show a woman embracing her returning man.

\section{References}

Allan, Stuart (1998) 'News from Nowhere: Televisual News Discourse and the Construction of Hegemony', in Bell, Allan \& Garrett, Peter: Approaches to Media Discourse. Oxford: Blackwell.

Barthes, Roland (1964) Rhétorique de l'image. Communications. Abbeville.

Barthes, Roland (1957) Mythologies. Paris: Editions du Seuil.

Chilton, Paul A. (1996) Security Metaphors. Cold War Discourse from Containment to Common House. New York: Peter Lang.

Chilton, Paul A. \& Lakoff, George (1995) 'Foreign Policy by Metaphor', in Christina Schäffner \& Wenden, Anita L. (ed.) Language and Peace. Aldershot: Dartmouth. 
Chilton, Paul A. (1995) 'Getting the Message Through - Metaphor and the Legitimation of the Gulf War', in Reither, Ruth: Sprache im Konflik: zur Rolle der Sprache in sozialen, politischen und militärischen Auseinandersetzung. Berlin: de Gruyter.

Cohn, Carole (1987) 'Sex and Death in the Rational World of Defense Intellectual', Signs: Journal of Women in Culture and Society 12(4): 687-718.

Di Stephano, Christine (1983) 'Masculinity as Ideology in Political Theory: Hobbesian Man Considered', Women's Studies International Forum 6(6): 633-644.

Elshtain, Jean Bethke (1987) Women and War. NewYork: Basic Books.

Enloe, Cynthia (1990) Bananas, Beaches, and Bases: Making Feminist Sense of International Politics. Berkeley: University of California Press.

Gramsci, Antonio (1978) Selections from the Prison Notebooks. London: Lawrence.

Grönfors, Martti (2002) 'Could Osama bin Laden Have Been a Woman? Masculinity and September 11', in Scraton, Phil: Beyond September 11. London: Pluto Press.

Hooks, Bell (1995) 'Feminism and Militarism: A Comment', Women's Studies Quarterly, 3-4: 58-64.

Ivie, Robert L. (2003) Evil Enemy v Agonistic Other: Rhetorical Constructions of Terrorism. Paper at the Conference War, Law and Rhetoric: University of Bergen.

Jeffords, Susan (1989) The Remasculinization of America: Gender and the Vietnam War. Bloomington: Indiana University Press.

Keller, Evelyn Fox (1985) Reflections on Gender and Science. New Haven: Yale University Press.

Lakoff, George (1995) 'Metaphor, Morality, and Politics, or Why Conservatives have Left Liberals in the Dust', Social Research, Spring.

Lakoff, George \& Johnsen, Mark (1999) Philosophy in The Flesh. New York: Basic Books.

Lind, Michael (2003) Made in Texas. George W Bush and the Southern Takeover Of American Politics. New York: Basic Books.

Lippe, Berit von der (1999) Metaforens Potens. Oslo: Oktober forlag.

Niva, Steve (1998) 'New World Order: Masculinity and the Gulf War', in Zalewsky, Marysia \& Parpart, Jane (ed). The 'Man': Questions in International Relations. Boulder and Oxford: Westview Press.

Schechter, Danny (2003) Media Wars. News at a Time of Terror. Maryland: \& Littlefield.

Tickner, J. Ann (1992) Gender in International Relations. New York: Columbia University Press.

\section{See new book from Nordicom}

Global War - Local Views. Media Images of the Iraq War. Stig A. Nohrstedt \& Rune Ottosen (eds.), Göteborg, Nordicom 2005, 279 p., ISBN 91-89471-33-4.

Berit von der Lippe, Associate Professor, Department of Communication, Culture and Language, Norwegian School of Management, N-0442 Oslo, berit.v.d.lippe@bi.no 